\title{
Geotechnical analysis of optimal parameters for foundations interacting with loess area
}

\author{
Olha Dubinchyk ${ }^{1, *}$, Dmytro Bannikov ${ }^{1}$, Vitalii Kildieiev ${ }^{1}$, and Vitalii Kharchenko ${ }^{1}$ \\ ${ }^{1}$ Dnipro National University of Railway Transport named after Academician V. Lazaryan, 49010, \\ Dnipro, Lazaryan Str., 2, Ukraine
}

\begin{abstract}
The article highlights results of the geotechnical analysis of the stress and strain state for the base of a subsoil massif under its interaction with the strip foundations. The massif is represented by loess soils which while soaking give overtime subsidences that complicate the operation of a building or a structure. Through geotechnical iterative research, optimization of the parameters for strip foundations on four axes at a fourstoreyed residential building is carried out. Checks are performed on two groups of limiting states for scenarios of soil occurrence in natural, moistened and compacted states. The optimum dimensions in the width of strip foundations are selected, they give approximately the same strain values of the base after the creation of the soil bedding with its layer-bylayer compaction. The relevance of this research is to develop optimal parameters in the design of strip foundations for shallow depth on subsidental loess soils.
\end{abstract}

\section{Introduction}

Geomechanics, as a science, combining the mechanics of rocks and underground structures tends to analyze workings and structures that lie in sufficiently hard rocks at deep depths [1]. Geotechnics, based on soil mechanics and structural mechanics, examines structures affecting the weak massifs formed by soils [2]. Given all the differences between these varieties of Earth science, one should determine the main conceptual feature that unites them. It is the principle of the interaction between feats of engineering (from mines at considerable depths [3] to foundations of shallow depth [2]) and the natural environment which is rock or subsoil massif [4].

It is the diversity of soil and rock conditions that by Protodyakonov's scale are in range $f=0.5 \ldots 50$, dictates the adoption of geotechnical or geomechanical tools which will fully enables the interaction of the engineering structure and the underlying or surrounding massif. It should also be noted that geotechnical analysis of the very soft soils ( $f=0.5 \ldots 1.2$ ), which, unlike the hard ones, have the features of deformation under load and in time, is of particular importance in the case of planting soils, which are forested ones.

These soils occupy up to $35 \%$ of the territory of Ukraine, the thickness of their layers

\footnotetext{
*Corresponding author: alexeytutkin@gmail.com
} 
lying in the soil massif can range from several centimeters to tens of meters [1]. Loess and loesslike loams are continental sediments, consisting mainly of dusty particles of $0.05 \ldots 0.005 \mathrm{~mm}$ (more than $50 \%$ ) and a significantly lower content of clay particles with a size of less than $0.0005 \mathrm{~mm}$ (not more than $10 \ldots 15 \%$ ). The amount of dust particles can reach $90 \%$.

Particle density of loess soils varies within $2.6 \ldots 2.75 \mathrm{~g} / \mathrm{cm}^{3}$ depending on the mineralogical composition. The density depends on the mineral composition, structure and water content and varies from 1.33 to $2.0 \mathrm{~g} / \mathrm{cm}^{3}$. Loess soils are characterized by high porosity and the presence of macropores that can reach $3 \mathrm{~mm}$ in diameter. Usually, the porosity of loess soils varies from 40 to $60 \%$. The porosity ratio of planting loesslike loams can be higher than 0.9 [5].

Loess soils of natural moisture and undisturbed structure have high strength and low deformability. Their use as soil bases for the foundations of buildings or structures in such state is not limited. The compression properties of loess soils of natural humidity do not differ from ordinary low cramped soils. In this case, the value of squeezing coefficient and the total deformation modulus when the pressure changes up to $0.4 \ldots 0.5 \mathrm{MPa}$ depends little on the pressure.

However, when the interaction of loess soil with water while soaking during the operation of a building or structure results in a negative subsidence effect. Structural bonds of loess soils are conditioned by water-colloid and cementation bonds, they are low waterresistant, so they relate to structurally unstable soils. With increasing humidity in the soft soils, the following processes take place: when moisture enters the soil, the calcite dissolves, the clay particles moisten. In this case, the water films around the clay particles thicken and wedge open them. As a result, the macrostructure of soil is destroyed, its strength sharply decreases and it takes on the property of being strongly compressed under load. Therefore, at a constant value of the compaction pressure under the impact of moistening, the porosity ratio changes abruptly, which indicates a radical change in the structure [6].

The problem in the existence of loess soils that form the subsoil massifs, in geotechnics is posed as follows: the design of foundations requires detailing engineering-geological studies, experiments of soil samples with further prediction in deformation of soil under loading, as well as potential reinforcement by various methods. Prediction has a scenariobased nature, since the foundation of a building or structure is checked at different states of a subsoil loesse, layered or inhomogeneous massif $[9,10]$. However, most often this prediction process ends only with the conclusion concerning the further foundation operation in various conditions. Therefore, optimization of its characteristics, for example, geometric ones, is a topical scientific and technical task that can be solved in analysing the prediction results.

\section{Methods}

According to regulatory requirements, the subsoil massif of construction sites, which are composed of subsidental soils, depending on the possibility in occurrence of soil subsidence by its own weight are divided into two types [9]: type I are soil conditions in which soil subsidence from external loading is possible, and soil subsidence from its own weight is absent or does not exceed $5 \mathrm{~cm}$; type II are soil conditions in which, in addition to soil subsidence from external loading, their subsidence from own weight is possible and its value exceeds $5 \mathrm{~cm}$.

For buildings on loess soil, several types of foundation structures are used on the existing strata of the loess soil, depending on the category of subsidence. If the strata of the subsidence soil is small and the roof of the stable lower bed is achievable, then the 
subsidental layer is cut through and the foundation rests upon a reliable soil. In the case when strata of the subsidental zone is large, then the foundation is placed in this layer, but measures are being taken to compact with heavy rammers, jet grouting piles, or practice cutting the loess soil and its replacing with stronger soils or by these loess soils by smaller strata with layer-by-layer compaction (creation of soil bedding).

According to the constructive solution of the building, for the optimization of its foundations we collected loads on the strip foundations that interact with subsidental strata (Fig. 1), their values are shown in Table 1.

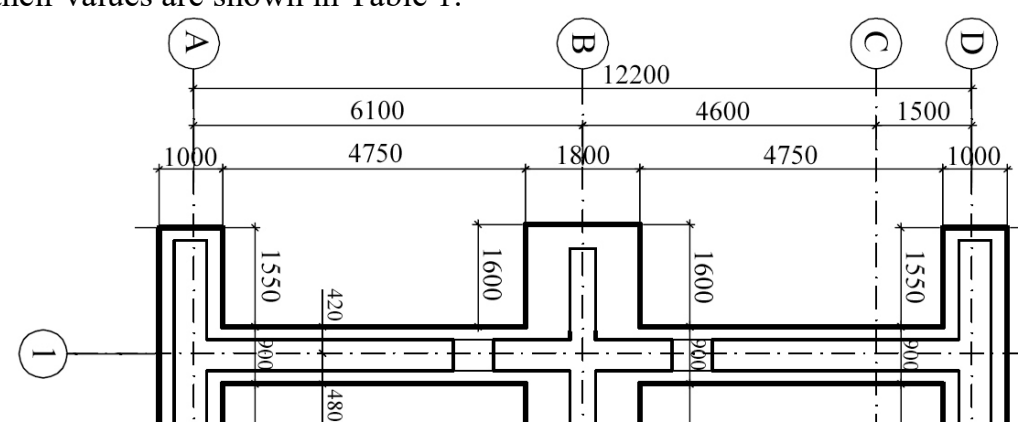

1)

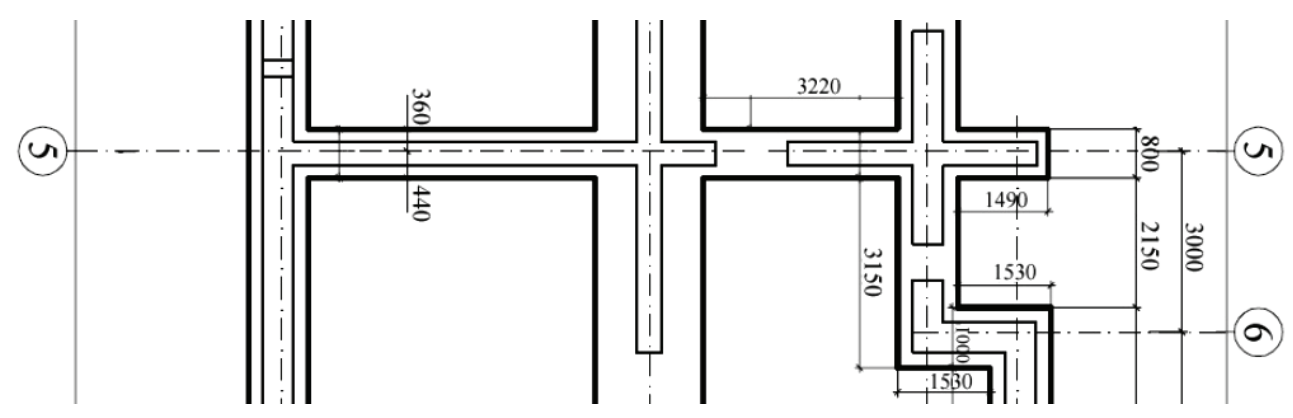

2)

Fig. 1. Fragments of the structures for foundations: 1) with axes 1, D and B; 2) with axis 5.

Table 1. Values of composite loads.

\begin{tabular}{|c|c|c|c|}
\hline $\begin{array}{c}\text { Axis } \\
\text { number }\end{array}$ & Characteristic value & Operation load & Design ultimate load \\
\hline Axis D & $231.56 \mathrm{kN} / \mathrm{m}$ & $231.56 \mathrm{kN} / \mathrm{m}$ & $261.63 \mathrm{kN} / \mathrm{m}$ \\
\hline Axis B & $300.83 \mathrm{kN} / \mathrm{m}$ & $300.83 \mathrm{kN} / \mathrm{m}$ & $342.58 \mathrm{kN} / \mathrm{m}$ \\
\hline Axis 1 & $123.39 \mathrm{kN} / \mathrm{m}$ & $123.39 \mathrm{kN} / \mathrm{m}$ & $135.73 \mathrm{kN} / \mathrm{m}$ \\
\hline Axis 5 & $115.55 \mathrm{kN} / \mathrm{m}$ & $115.55 \mathrm{kN} / \mathrm{m}$ & $127.11 \mathrm{kN} / \mathrm{m}$ \\
\hline
\end{tabular}

For all temporary loads for the overlaps of a multi-storeyed building, the characteristic values of loads should be reduced with consideration to the combination factor $\psi_{n 1}$, which is calculated by the formulas:

$$
\psi_{n 1}=0.4+\frac{\psi_{A 1}-0.4}{\sqrt{n}},
$$

where $n$ is the total number of overlaps. 
The characteristic values for structure weight were determined by the design dimensions and specific gravity of the materials and soils. The operational design values of the structure weight and soils are taken to be equal to the characteristic one. The limiting design value of the structure weight and soils is determined by multiplying the characteristic value on the reliability coefficient by the limiting load.

The loads and impacts on the foundations transferred to the foundations of buildings or structures were determined according to the provisions [11]. The calculated values of loading from soil weight for the first and second limiting states were adopted using the characteristic values of the specific gravity of the soil, determined during engineeringgeological surveys, with the load safety factors $\gamma_{f}$.

According to the engineering-geological conditions, the base of the foundations, having been calculated, compose of subsidental soils, which in conditions of soaking can dramatically increase the uneven subsidence while reducing the bearing capacity of the foundation. Therefore, several variants of foundations were considered and proposed [9]. Through the iterative study, the parameters of strip foundations along the axes D, B, 1 and 5 of a residential four-storeyed building were optimized and checks were performed on two groups of limiting states.

\section{Results and discussions}

If the loess soils are in a dry state, then the bearing capacity of the base is provided with a reserve. However, according to engineering-geological conditions, the base of the foundations is composed of subsidence soils, which in the conditions of soaking change their physical characteristics and simultaneously the subsidence of the foundation increases sharply and the bearing capacity of the foundation decreases.

The bearing capacity of the base (the first group of limiting states) is performed when observing the criterion in general case:

$$
\sigma \leq \sigma_{R}
$$

or

$$
p \leq R
$$

where $\sigma_{R}$ is calculated stress; $p$ or $\sigma$ is medium pressure or stress directly below the foundation bed; $R$ is design resistance for soil of a base under the foundation bed.

Foundation subsidence $s$ (the second group of limiting states) using a design scheme in the form of a linearly deformable half-space by the method of layer-by-layer summability is calculated by the formula

$$
s=\beta \sum_{i=1}^{n} \frac{\left(\sigma_{z p, i}-\sigma_{z \gamma, i}\right) h_{i}}{E_{i}},
$$

where $\beta$ is dimensionless coefficient that equals to $0.8 ; \sigma_{z p, i}$ the average value of the vertical normal stress from the external load in the $i$-th layer of soil on the vertical line passing through the center of the foundation bed; $h_{i}$ is thickness of the $i$-th layer of soil, it is accepted no more than 0.4 of foundation width; $n$ is the number of layers into which the compressed base strata is divided; $\sigma_{z \gamma, i}$ is the average value of the vertical stress from the own weight of soil extracted from the pit in the $i$-th layer of soil on the vertical line passing 
through the center of the bed, at depth $z$ from the foundation bed; $E$ is the deformation modulus of the $i$-th soil layer with a primary load branch.

Tables 2 and 3 present the calculation data of foundation on soils in two states that comply with the scenarios of its operation. These and the following tables accept the following designations of values: $b$ is the width of the strip foundation, $\mathrm{m} ; R$ is calculated soil resistance of the base under the foundation bed, $\mathrm{kPa} ; p$ is the average pressure directly under the foundation bed, $\mathrm{kPa} ; \delta$ is the relative error between the mean pressure under the foundation bed and the calculated soil resistance of the base, $\%$.

Table 2. Calculated values (the unmoistened state episode).

\begin{tabular}{|c|c|c|c|c|}
\hline \multirow{2}{*}{ Calculated values } & \multicolumn{4}{|c|}{ Axis of the foundation } \\
\cline { 2 - 5 } & $\mathrm{C}$ & $\mathrm{B}$ & 1 & 5 \\
\hline$b$ & 1.1 & 1.4 & 0.7 & 0.6 \\
\hline$R$ & 247.5 & 250.7 & 243.2 & 242.1 \\
\hline$p$ & 232.0 & 223.1 & 204.5 & 202.6 \\
\hline$\delta$ & -6.25 & -11.01 & -15.93 & -16.34 \\
\hline
\end{tabular}

Table 3. Calculated values (the moistened state episode).

\begin{tabular}{|c|c|c|c|c|}
\hline \multirow{2}{*}{ Calculated values } & \multicolumn{4}{|c|}{ Axis of the foundation } \\
\cline { 2 - 5 } & $\mathrm{D}$ & $\mathrm{B}$ & 1 & 5 \\
\hline$b$ & 1.1 & 1.4 & 0.7 & 0.6 \\
\hline$R$ & 168.9 & 171.6 & 165.2 & 164.3 \\
\hline$p$ & 232.0 & 223.1 & 204.5 & 202.6 \\
\hline$\delta$ & $\begin{array}{c}37.4 \\
\text { (overload) }\end{array}$ & $\begin{array}{c}29.9 \\
\text { (overload) }\end{array}$ & $\begin{array}{c}23.7 \\
\text { (overload) }\end{array}$ & $\begin{array}{c}23.3 \\
\text { (overload) }\end{array}$ \\
\hline
\end{tabular}

As the foundations on all axes have significant overload, that is to say they do not have adequate bearing capacity, it is necessary to change the soil properties of the base by means of a surface (layer-by-layer) mechanical seal, which is performed by ramming, vibroramming or combining the above methods, including soaking for subsidental soils.

For these engineering-geological conditions, a surface (layer-by-layer) mechanical seal is performed and a soil bedding is designed. The sealing is performed in layers. The thickness of the layer was equal to $30 \mathrm{~cm}$. To accurately determine the number of roller passages and to define the rational layer thickness, a test soil compacting is carried out with an optimum humidity $W_{0}=0.15$, with a limit deviation of $\pm 15 \%$, on a strip with length of $15 \mathrm{~m}$. At least six soil samples (top, middle and bottom of the suspended bed) are selected to determine density and humidity. When creating soil beddings, the test seal is carried out at three variants: the number of a roller passage is of 6,8 and 10 .

Verification must be carried out on the basis of geotechnical monitoring and laboratory testings. Each subsequent layer of soil is compacted immediately after its filling and leveling continuously. To determine the moisture and soil density after the compaction of each layer, samples are taken at checkpoints assigned at the rate of 1 point for every $300 \mathrm{~m}^{2}$, but not less than two per object [9]. The number of samples at each point was not less than three. Sampling was performed from the middle of each rammed layer.

The soil bedding is designed in accordance with the requirements $[9,10]$. Thickness of soil bedding is $1.80 \mathrm{~m}$; six layers of compacted soil, selected from the pit with thickness of $30 \mathrm{~cm}$. The pit bottom under the soil bedding is compacted to a skeleton density $\rho_{d}=1.7 \mathrm{~g} / \mathrm{cm}^{3}$. The soil bedding is made of local loess loam at $W_{0}=0.15$, with a limit 
deviation of $\pm 15 \%$ from $W_{0}$. In case of deviation from the set humidity value, moistening or drying is performed. If moistening is necessary, if the soil moisture is $15 \%$ or more below the optimum, if the soil moisture is below the optimum by $15 \%$ or more, the soil in the cavalier is laid in layers of $25 \mathrm{~cm}$ with simultaneous moistening.

Table 4 shows the data for the calculation of foundations on compacted soils.

Table 4. Calculated values (episode of compacted soils).

\begin{tabular}{|c|c|c|c|c|}
\hline \multirow{2}{*}{ Calculated values } & \multicolumn{4}{|c|}{ Axis of the foundation } \\
\cline { 2 - 5 } & $\mathrm{D}$ & $\mathrm{B}$ & 1 & 5 \\
\hline$b$ & 1.1 & 1.4 & 0.7 & 0.6 \\
\hline$R$ & 397.72 & 402.86 & 390.89 & 389.18 \\
\hline$p$ & 232.01 & 223.09 & 204.46 & 202.58 \\
\hline$\delta$ & -41.67 & -44.62 & -47.69 & -47.95 \\
\hline
\end{tabular}

For the obtained dimensions of strip foundations, the total deformation of the base and structure was calculated using a design scheme in the form of a linear-deformed half-space by the layer-by-layer method (Table 5).

Table 5. The obtained initial values of geometric parameters.

\begin{tabular}{|c|c|c|c|c|}
\hline \multirow{2}{*}{ Calculated values } & \multicolumn{4}{|c|}{ Axis of the foundation } \\
\cline { 2 - 5 } & $\mathrm{D}$ & $\mathrm{B}$ & 1 & 5 \\
\hline Strip foundation width $b, \mathrm{~m}$ & 1.1 & 1.4 & 0.7 & 0.6 \\
\hline Foundation subsidence $s, \mathrm{sm}$ & 1.51 & 1.69 & 0.79 & 0.68 \\
\hline
\end{tabular}

For structures on loess soils it is desirable to have approximately equal numerical values of deformation in the base subsidence on all axes of the building. Due to this, some dimensions of the strip foundation width were changed (Table 6).

Table 6. Optimized values of geometric parameters.

\begin{tabular}{|c|c|c|c|c|}
\hline \multirow{2}{*}{ Calculated valus } & \multicolumn{4}{|c|}{ Axis of the foundation } \\
\cline { 2 - 5 } & $\mathrm{D}$ & $\mathrm{B}$ & 1 & 5 \\
\hline Strip foundation width $b, \mathrm{~m}$ & 1.3 & 1.6 & 0.7 & 0.6 \\
\hline Foundation subsidence $s, \mathrm{sm}$ & 1.43 & 1.62 & 0.79 & 0.68 \\
\hline
\end{tabular}

The limiting value of the combined deformation of the base and structure for residential multi-storeyed frameless buildings with load-bearing walls of brickwork without reinforcement is $s_{u}=10 \mathrm{~cm}$ according to paragraph 7.9.4 [9]. That is, on all four axes, the condition of the calculation for deformation of bases is fulfilled.

\section{Conclusions}

Geotechnical analysis of the optimum parameters for foundations of a four-storeyed residential building was carried out with consideration to the results of engineering and geological surveys, data characterizing the purpose, structural features of the building, loads acting on foundations, as well as prediction of the operating conditions and economic capabilities of the customer.

On the basis of the calculations, the optimal design of the strip foundation on the compacted soil bedding was developed. At the same time, the possibility of a relative uniform deformation of the subsidence of the loess base under the foundation of a fourstoreyed residential building was taken into account. The option optimized on the basis of 
strength and deformability calculations provides the most complete use of the characteristics of loess base soils.

The decision taken meets the requirements of safety of people's habitation, serviceability and durability of the structure.

\section{References}

1. O. Voloshyn, O. Riabtsev (2019). Some important aspects of rock mechanics and geomechanics. E3S Web of Conferences, International Conference Essays of Mining Science and Practice, 109 (2019). https://doi.org/10.1051/e3sconf/201910900114

2. Shvets, V.B., Shapoval, V.G., Petrenko, V.D., Andreyev, V.S., Selikhova, T.A., Tiutkin, A.L. (2008). Fundamenty promyshlennykh, grazhdanskikh i transportnykh sooruzheniy na sloistykh gruntovykh osnovaniyakh. Dnepropetrovsk: Nova ideolohiia

3. O. Voloshyn, O. Riabtsev (2013). Studies of stationary supporting zone sizes varied in the course of mining operations in deep horizons. Annual Scientific-Technical Collection - Mining of Mineral Deposits, 71-76

4. Bulychev, N.S. (1994). Mekhanika podzemnykh sooruzheniy. Moskva: Nedra

5. Krayev, V.F. (1971). Inzhenerno-geologicheskaya kharakteristika porod lessovoy formatsii Ukrainy. Kiyev: Naukova dumka

6. Krutov, V.I. (1982). Osnovaniya i fundamenty na prosadochnykh gruntakh. Kiyev: Budivelnyk

7. O. Dubinchyk, V. Petrenko, D. Ihnatenko, V. Kildieiev (2019). Comprehensive analysis of the retaining pile structure with the determining the stability factor by numerical methods. E3S Web of Conferences, International Conference Essays of Mining Science and Practice, 109 (2019). https://doi.org/10.1051/e3sconf/ 201910900020

8. Tiutkin, O.L., Dubinchyk, O.I., Kildieiev, V.R. (2018). Analiz rezultativ stiikosti porodnykh skhyliv, skladenykh neodnoridnymy ta sharuvatymy gruntamy, Bridges and tunnels: Theory, Research, Practice, 14, 81-92

9. DBN V.2.1-10-2009 (2009). Osnovy ta fundamenty sporud. Osnovni polozhennia proiektuvannia. Kyiv: Minrehionbud Ukrainy

10. DBN V. 1.1-5-2000 (2006). Budynky i sporudy na pidrobliuvanykh terytoriiakh i na prosidaiuchykh gruntakh (Chastyna II. Budynky i sporudy na prosidaiuchykh gruntakh). Kyiv: Minbud Ukrainy

11. DBN V.1.2-2:2006 (2006). Navantazhennia i vplyvy. Normy proektuvannia. Kyiv: Minbud Ukrainy 